\title{
Shear resistance of expensive concrete beams reinforced with FRP longitudinal bars
}

\author{
Viktar Tur $^{1 *}$, Aliaksandr Varabei $^{1}$ \\ ${ }^{1}$ Brest State Technical University, 224017, Moskovskaya 267, Brest, Belarus
}

\begin{abstract}
This paper presents the results of testing beams reinforced with FRP in combination with expansive concrete. Failure modes under uniformly distributed loading and ultimate forces recorded in tests are described. The results of comparison of shear resistance models against the background of experimental data are presented.
\end{abstract}

Keywords: Expensive concrete, FRP reinforcement, Shear resistance, Uniformly distributed load, Beams,

\section{Introduction}

Recently, concrete elements reinforced with fiber reinforced polymers (FRP) bars widespread in the building industry. This type of FRP-reinforcement has become alternatives to conventional steel reinforcement for concrete structures owing to their noncorrosive and non-magnetic properties [1]. Classification, main physical and mechanical properties of the FRP reinforcement are presented in [2]. It should be pointed, that despite some advantages over steel bars utilization of the FRP bars have some limitations, mainly in case of the bending elements. Concrete members reinforced longitudinally with FRP bars develop wider and deeper cracks than those reinforced with steel due mainly to the relative low elastic modulus of FRPs [3]. As shown in numerous publications [4, 5] wider cracks decrease the shear resistance contributions from aggregate interlock and residual tensile stresses, where as deeper cracks reduce the shear resistance contribution from the uncracked concrete in compression. Additionally, owing to the relatively wider cracks and small transverse strength of FRP bars, dowel action contribution to shear resistance can be very small compared with that of steel reinforcement [6]. Hence, the overall shear resistance of concrete members (elements) reinforced with longitudinal FRP bars is lower than that of concrete members reinforced with steel reinforcement.

The main practical difficult that is faced during such construction is the stirrups. It is seen that most of the FRP reinforced beams make use of steel stirrups and minimum cover thickness is provided, which nullifies the possibility of overall cross section reduction. Due to the difference in mechanical properties in between FRP bars and steel bars, the failure mode of FRP-reinforced concrete beams is different from that of RC-beams [6]. For FRP $\mathrm{RC}$ beams without stirrups, shear failure generally occurs in association with the formation of one or more diagonal cracks, which for simplicity are assumed to form linearly as suggested by Hoang and Jensen [7], Hong and Nelsen [8], Jensen et al [9]. The applied

\footnotetext{
${ }^{*}$ Corresponding author: profturvic@gmail.com
} 
shear stresses in a cracked reinforced concrete member without transverse reinforcement are resisted by various shear mechanisms. Most of the shear predictions models and design procedures and standards assume that the shear resistance mechanisms for FRP reinforced member will contribute in a similar manner to the nominal shear capacity of concrete members reinforced with steel [3]. The ACI Committee-445 [2] report identified that shear transfer mechanisms mainly depend on the concrete strength $\left(f_{c}\right)$ and the depth of uncracked zone which is a function of the longitudinal reinforcement properties. Also, arch action occurs in deep beams or members in which shear to depth ratio $(a / d)$ is less than 2,5.

The excessive amount of FRP needed to resist shear could be both costly and likely to create reinforcement congestion problems. The following main parameters were considered to affect the shear strength of FRP-reinforced concrete members such as, the concrete compressive strength $\left(f_{c}\right)$, beam width $\left(b_{w}\right)$, effective depth $(d)$, shear span-to-depth ratio $(a / d)$, reinforcement ratio $\left(\rho_{f}\right)$, axial stiffness of reinforcing bars $\left(\rho_{f} E_{f}\right)$.

One of the possible solutions to avoid shear failure of such type beam is prestressing of the FRP bars. The physico-chemical method of FRP bars pretensioning is considered as an alternative to traditional mechanical method that allows to achieve an effective volumetric stress-strain state in the prestressed member, doesn't need for special devices and anchorage systems as well as being a "gradual and soft" pretensioning process, allows to avoid excessive relaxation strains development in reinforcement. It is theoretically assumed that achieved in the self-stressed FRP reinforced beams initial volumetric stress-strain state has a positive influence on the member crack resistance moment increasing, limitation of exceeding deformation (deflections) and crack opening development [10].

This paper reports the experimental study carried out to determine the behaviour of FRP reinforced beams under uniformly distributed load, verify and compare various proposed shear resistance models of FRP reinforced members based on obtained test results.

\section{Experimental investigation}

Present study investigates the behaviour of members reinforced with FRP (two types GFRP and CFRP) in combination with expansive (self-stressing) concrete. The main aim for incorporating expansive concrete into FRP reinforced beams is to explore the possibility of increasing of shear resistance of members.

Program of experimental investigations listed in Table 1. Experimental studies were carried out on two series of rectangular cross section self-stressing concrete beams reinforced with GFRP and CFRP bars. All investigated beams had rectangular cross-section $b \times h=120 \times 300 \mathrm{~mm}$ and length $l=3000 \mathrm{~mm}$. Beams were reinforced with GFRP (Maperod G) and CFRP (Maperod C) bars. Geometry, reinforcement arrangement and basic parameters of beams shown in Figure 1.

Program of experimental investigations composed in such way that adopted amount of FRP-reinforcement (reinforcement ratio) provided near the equal value of ultimate load under shear failure.

Main mechanical parameters of two types of utilized of FRP bars listed in Table 2.

Expansive concrete mix nominal composition per $1 \mathrm{~m}^{3}$ are listed in Table 3. Average values of the self-stressing concrete characteristics are listed in Table 1.

Demolding of the specimens was carried out the next day after casting, when selfstressing concrete achieved compressive strength $11 \mathrm{MPa}$ at average. Immediately after demolding, specimens were immersed in water and cured there until stabilization of self-stressing concrete expansion was reached. And then self-stressed beams were tested under static loading with monotonically increasing uniformly distributed load (see Figures 2-3). 
Table 1. Program of investigations

\begin{tabular}{|c|c|c|c|c|c|c|c|c|c|}
\hline \multirow{2}{*}{ Series } & \multirow{2}{*}{$\begin{array}{l}\text { Unit } \\
\text { code }\end{array}$} & \multirow{2}{*}{$\begin{array}{c}f_{c, \text { cube }}, \\
\text { MPa }\end{array}$} & \multirow{2}{*}{$\begin{array}{l}f_{c m}, \\
\text { prism, } \\
\text { MPa }\end{array}$} & \multirow{2}{*}{$\begin{array}{c}f_{c m, c y l}, \\
\mathrm{MPa}\end{array}$} & \multirow{2}{*}{$\begin{array}{l}E_{\mathrm{cm}}, \\
\mathrm{GPa}\end{array}$} & \multirow{2}{*}{$\begin{array}{c}\text { Self- } \\
\text { stresses, } \\
f_{C E, k}, \\
\mathrm{MPa}\end{array}$} & \multicolumn{3}{|c|}{ Reinforcement } \\
\hline & & & & & & & Quanti-ty & $\begin{array}{l}A_{f r p}, \\
\mathrm{~mm}^{2}\end{array}$ & $\begin{array}{l}\rho l \\
\%\end{array}$ \\
\hline \multirow{2}{*}{ I } & $\begin{array}{c}\text { БІ- } \\
\text { 1СД18 }\end{array}$ & \multirow{2}{*}{7,6} & \multirow{2}{*}{51,1} & \multirow{2}{*}{7,2} & \multirow{2}{*}{31,7} & \multirow{2}{*}{2,55} & $\begin{array}{l}2 \varnothing 10 \\
\text { GFRP }\end{array}$ & 142,5 & 0,44 \\
\hline & $\begin{array}{c}\text { БІ- } \\
\text { 2СД18 }\end{array}$ & & & & & & $\begin{array}{l}2 \varnothing 10 \\
\text { GFRP }\end{array}$ & 142,5 & 0,44 \\
\hline \multirow{2}{*}{ II } & $\begin{array}{c}\text { БІІ- } \\
\text { ЗСД12 }\end{array}$ & \multirow{2}{*}{77,1} & \multirow{2}{*}{76,5} & \multirow{2}{*}{56,1} & \multirow{2}{*}{43,3} & \multirow{2}{*}{0,45} & $\begin{array}{l}2 \varnothing 10 \\
\text { GFRP }\end{array}$ & 142,5 & 0,44 \\
\hline & $\begin{array}{c}\text { БІІ- } \\
\text { 4УД12 }\end{array}$ & & & & & & $\begin{array}{c}\varnothing 10 \\
\text { CFRP }\end{array}$ & 73,9 & 0,23 \\
\hline
\end{tabular}

\section{Notes:}

$f_{c, \text { cube }}-$ - cube compressive strength at 28 days;

$f_{c m}$, prizma, - mean concrete compressive strength based on prisms $(100 \times 100 \times 400 \mathrm{~mm})$;

$f_{c m, c y l},-$ mean concrete compressive strength based on cylinders $(\varnothing 150, \mathrm{~h}=300 \mathrm{~mm})$;

$f_{C E, k}$ - self-stresses grade based on prisms $(100 \times 100 \times 400 \mathrm{~mm})$;

$A_{f r p}$ - area of FRP;

$\rho_{l}-$ longitudinal reinforcement ratio.
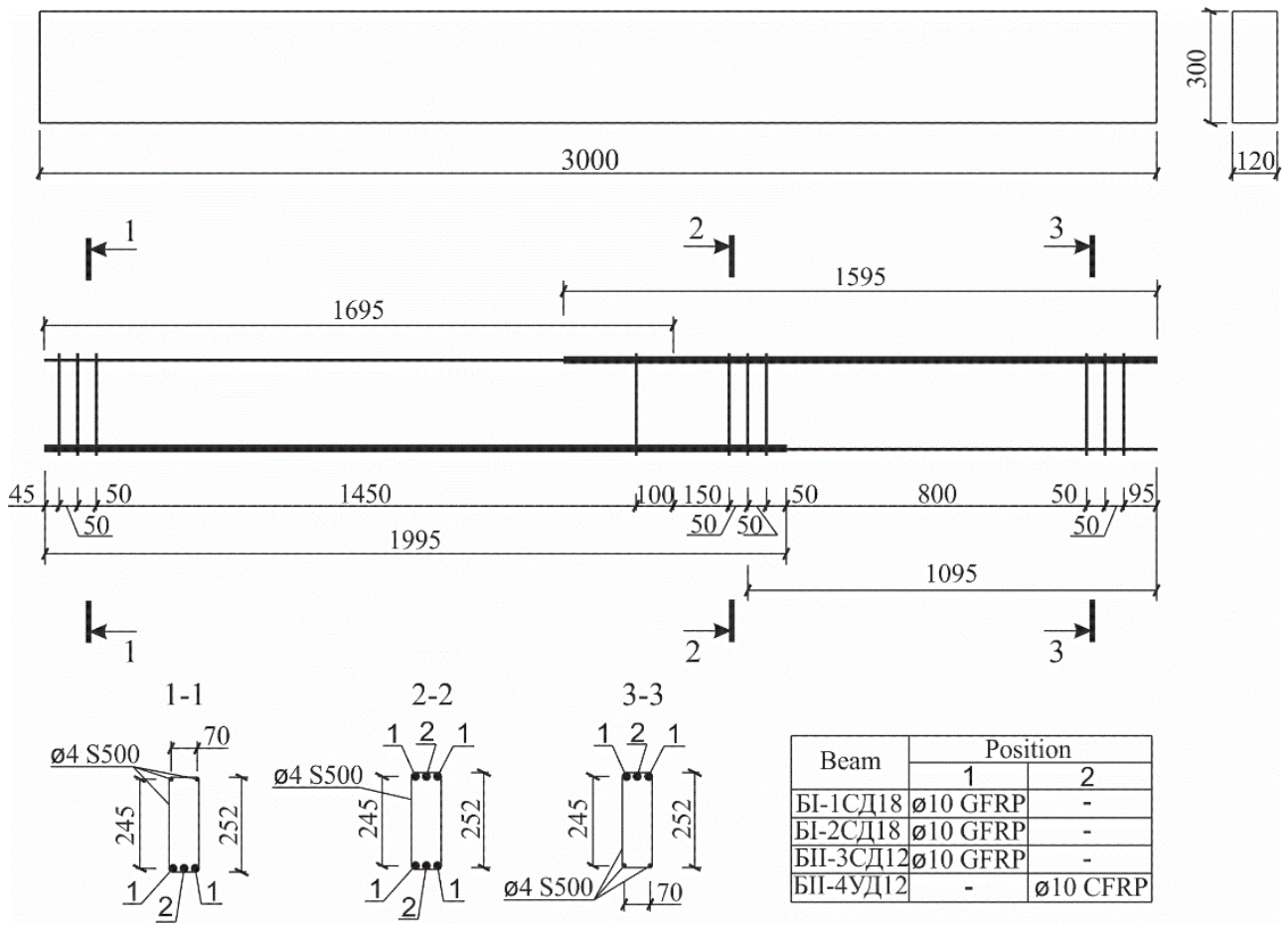

Fig.1. Geometry, reinforcement arrangement and parameters of tested beams 
Table 2. FRP reinforcement mechanical parameters

\begin{tabular}{|c|c|c|c|c|}
\hline Class & $\begin{array}{c}\text { Diameter } \varnothing, \\
\mathrm{mm}\end{array}$ & Strength, MPa & $\begin{array}{c}\text { Modulus of elasticity } \\
\text { Exx } 10^{3}, \mathrm{MPa}\end{array}$ & $\begin{array}{c}\text { Ultimate strain, } \\
\%\end{array}$ \\
\hline Maperod G & 10 & 760 & 40,8 & 2 \\
\hline Maperod C & 10 & 2000 & 155 & 1,5 \\
\hline
\end{tabular}

Table 3. Expansive concrete composition

\begin{tabular}{|c|c|c|c|c|c|c|}
\hline \multirow{2}{*}{ Series } & \multicolumn{6}{|c|}{$1 \mathrm{~m}^{3}$ in dry conditions, kg } \\
\cline { 2 - 7 } & Cement & Denka CSA & $\begin{array}{c}\text { Fine } \\
\text { aggregate }\end{array}$ & $\begin{array}{c}\text { Coarse } \\
\text { aggregate }\end{array}$ & Water, 1 & $\begin{array}{c}\text { Stachement } \\
2010\end{array}$ \\
\hline I & 510 & 90 & 600 & 960 & 240 & - \\
\hline II & 410 & 50 & 805 & 990 & 175 & 7,0 \\
\hline
\end{tabular}

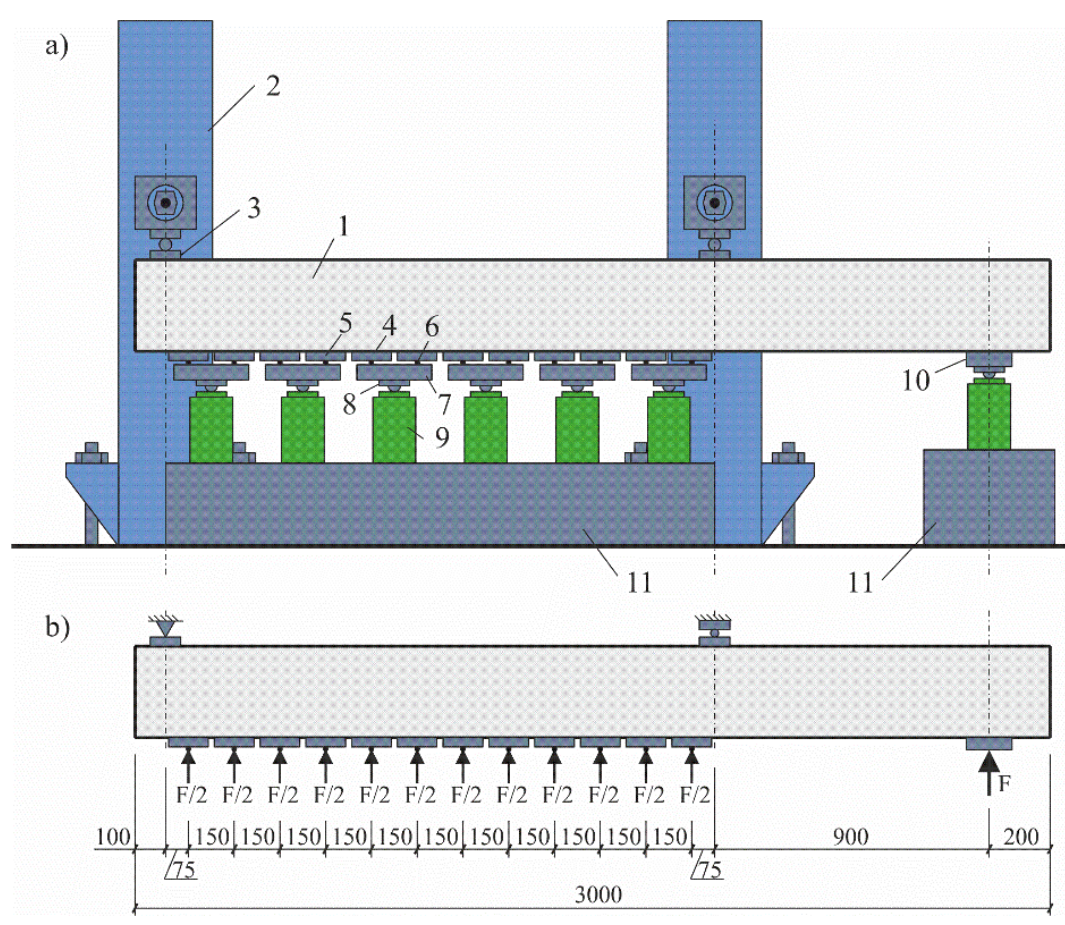

1 - experimental beam;

$2-2$ U-shaped steel frames connected to the strong floor;

$3-4$ steel supports $(100 \times 200 \times 30 \mathrm{~mm})$;

$4-13$ rubber bearings;

$5-12$ steel plates $(130 \times 130 \times 30 \mathrm{~mm})$;

6 - 12 steel bars $(\varnothing 14 \mathrm{~mm})$;

7 - steel plates $(245 \times 155 \times 50 \mathrm{~mm})$;

$8-7$ steel hinges;

$9-7$ hydraulic jacks $(250 \mathrm{kN})$;

10 - steel plates (150x150x40 mm);

11 - steel girder.

Fig.2. Test setup 


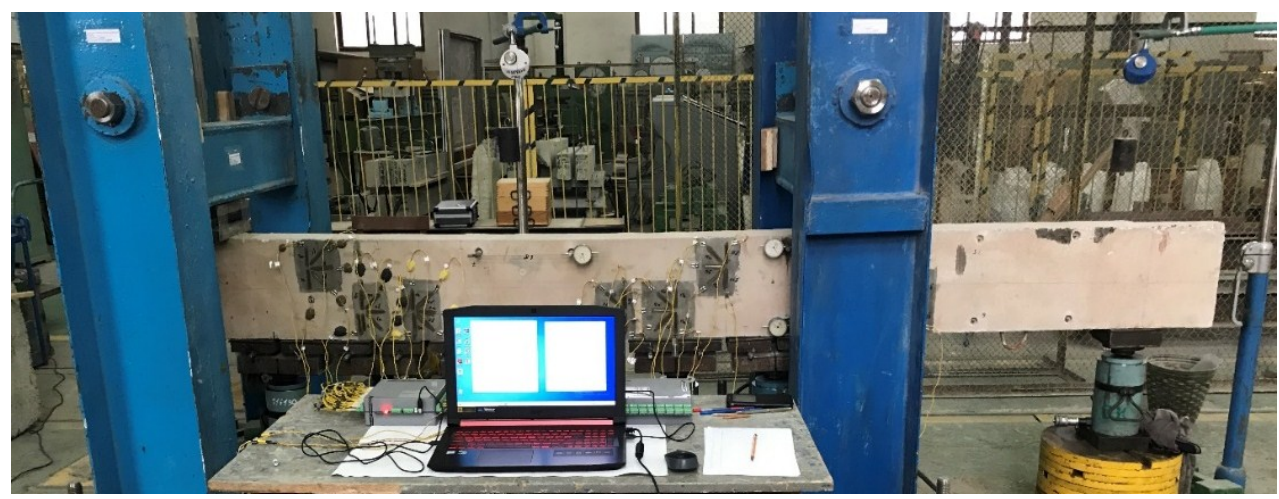

Fig.3. General view of test setup

The following values of self-stresses in concrete on the depth of the cross-section gravity center to the self-stressing concrete expansion stabilization was obtained for beams:

(1) БІ-1СД18 - 0,62 MPa (span) and 0,79 MPa (cantilever part);

(2) БІ-2СД18-0,78 MPa (span) and 0,89 MPa (cantilever part);

(3) БІІ-ЗСД12 and БІІ-4УД12 - shrinkage compensation only.

As follows from the test results the first flexural cracks in the span for all series of beams developed under load equal $0,4 . .0,5 q_{u}$. It should be pointed out that for the beams of the series IІ (БІІ-ЗСД12 and БІІ-4УД12) in which self-stresses absent, the flexural cracks developed not only in the span but in the cantilever (see Figure 4). Flexural cracks were distributed in near the same distance along the length of the beam span. Depth of the cracks observed from $50 \%$ to $80 \%$ of the height of the cross-section. The basic difference between failure mode for beams series I and series II was following: for beams series I observed shear failure mode in the span but for beams series II on the cantilever. Diagonal cracks were developed at the distance $\geq d$ from support and the inclination angle was registered equal to $\theta \approx 60 . .70^{\circ}$.

The results obtained within loading of self-stressed beams are presented in Tables 4-5 and shown in Figures 5-6. Observed cracking patterns and failure mode of the tested beams are illustrated in Figure 4.

As it can be seen from the static loading results listed in Table 1, initial volumetric stress-strain state obtained on the concrete self-stressing stage had a positive influence on the crack resistance moment increasing and on the reducing of the deflections (Fig. 4) as well crack opening.

The Table 4 presents the parameters of the observed diagonal cracks.

Most of the shear design incorporated in codes for the FRP reinforced concrete members have focused on modifying shear equations of steel reinforced concrete beams (see Table 5).

The shear resistance was calculated for various models based on the expressions given in $[11-13]$.

\section{Results and Discussion}

All results obtained from experimental studies and predicted by the models from codes [1113] are listed in Table 5. It is observed that the shear resistance predicted by prEN 1992-1-1 [11] is closer to the experimental values. However, it is found that the EN 1992-1-1 [12] and fib MC 2010 [13] under predicts the results compared to experimentally observed values. These will be discussed in detail in the further investigations. 
a)

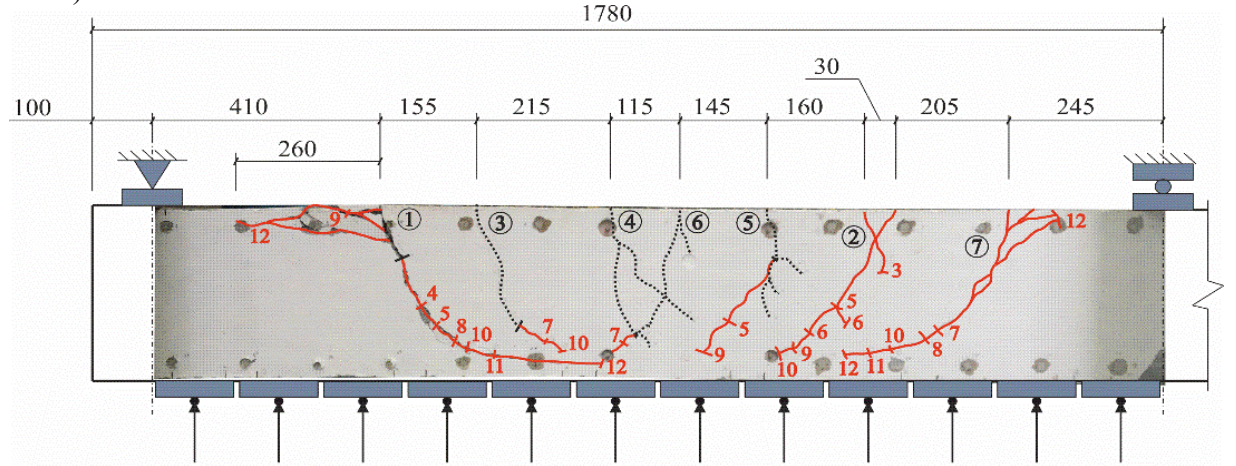

b)
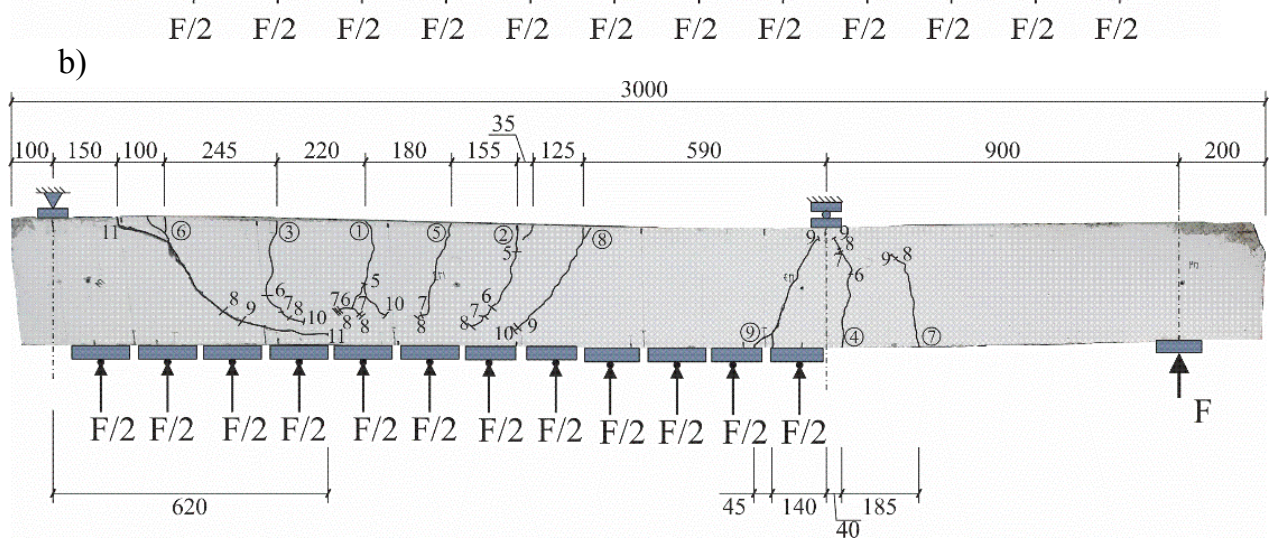

c)

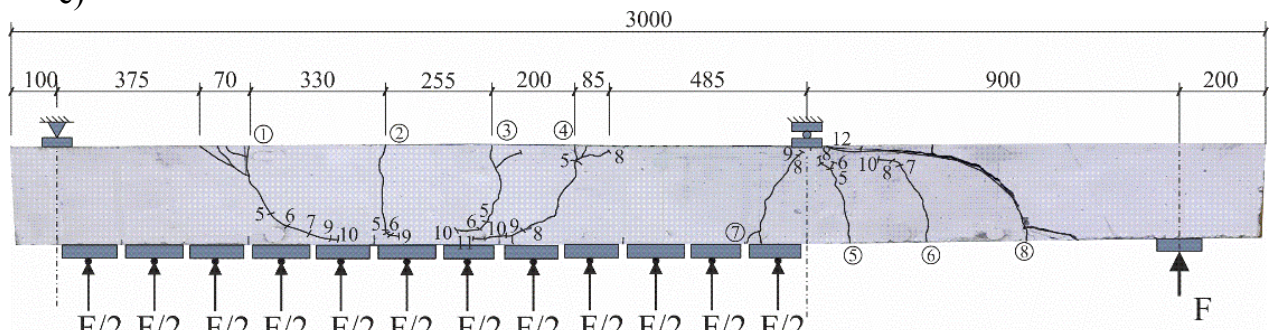

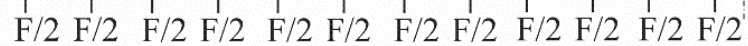

d)
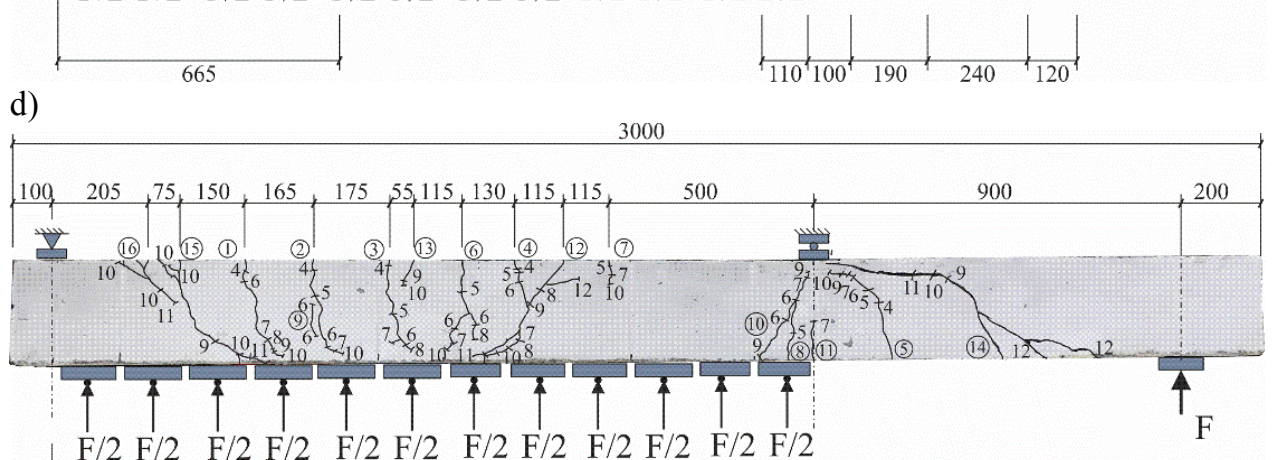

a - БІ-1СД18; b - БІ-2СД18; c - БІІ-3СД12; d - БІІ-4УД12

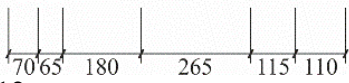

Fig.4. Cracks patterns for tested beams 
a) $\mathrm{M}$, $\mathrm{kN} \cdot \mathrm{m}$
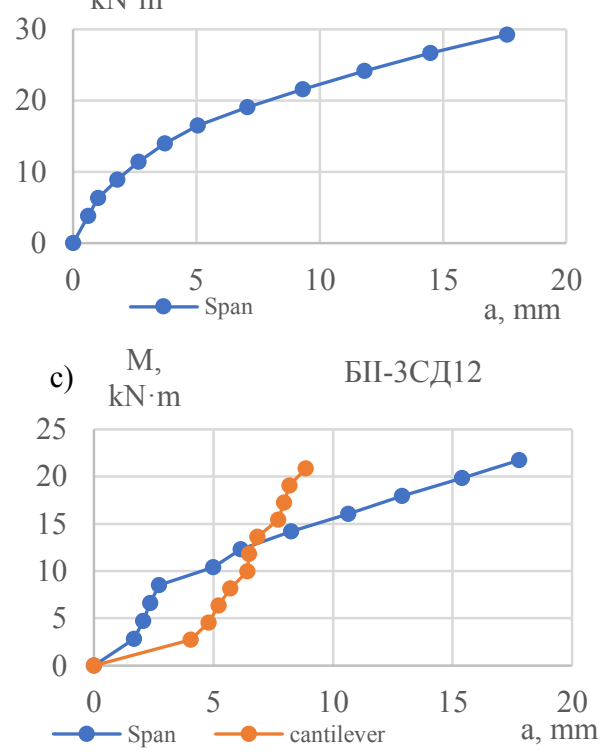

b)

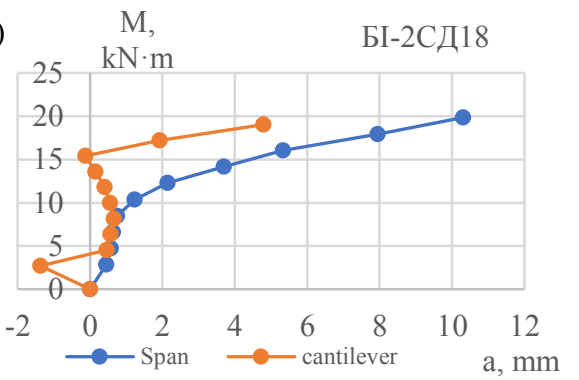

d) $\mathrm{M}$,

d) $\mathrm{kN} \cdot \mathrm{m}$

БІІ-4УД12

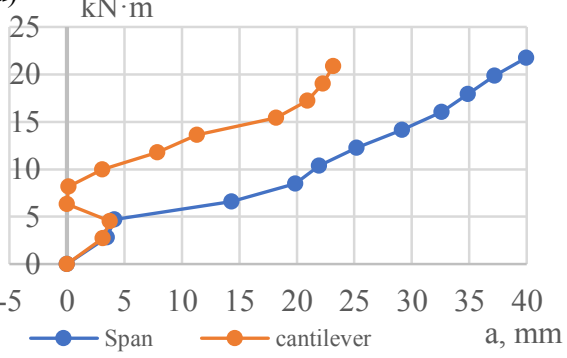

a - БІ-1СД18; b - БІ-2СД18; c - БІІ-3СД12; d - БІІ-4УД12

Fig.5. Relation "moment - deflection" for tested beams
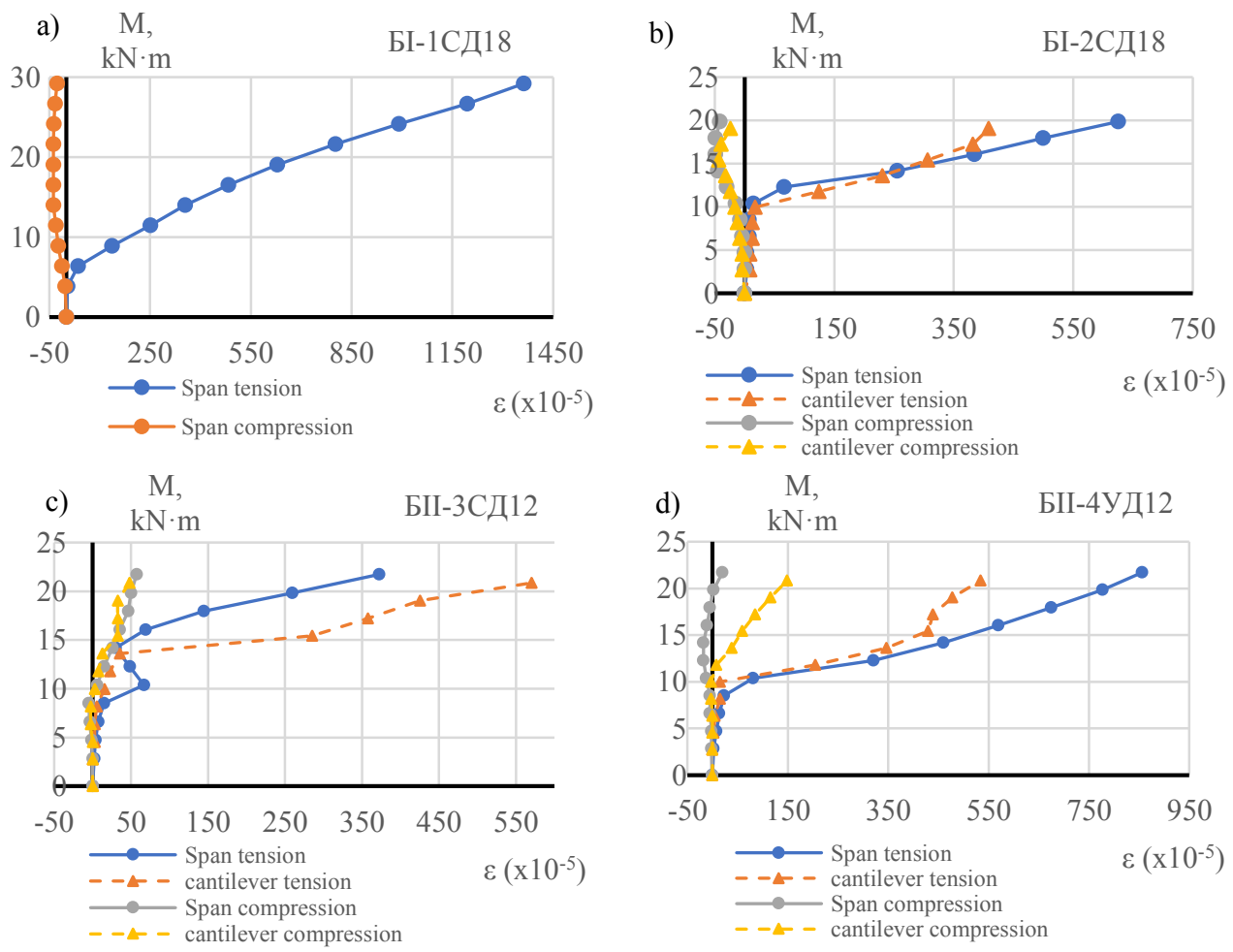

a - БІ-1СД18; b - БІ-2СД18; c - БІІ-3СД12; d - БІІ-4УД12

Fig.6. Relation "moment - strains" for tested beams 
Table 4. Parameters of the diagonal cracks

\begin{tabular}{|c|c|c|c|c|c|c|}
\hline Unit code & $\begin{array}{c}\text { № critical } \\
\text { crack (see } \\
\text { Fig. } 4 \text { ) }\end{array}$ & $\begin{array}{l}\text { lo, } \\
\mathrm{mm}\end{array}$ & $l_{\mathrm{sp}}, \mathrm{mm}$ & $\frac{M}{V \cdot d}$ & $\begin{array}{c}\max \\
\mathrm{wk}_{\mathrm{k}}, \mathrm{mm}\end{array}$ & $\begin{array}{l}\text { Inclination angle critical } \\
\text { crack, } \theta^{\circ}\end{array}$ \\
\hline $\begin{array}{c}\text { БІ-1СД18 } \\
\text { (без } \\
\text { нагружении } \\
\text { консоли) }\end{array}$ & 1 & 410 & 370 & 2,30 & 2,5 & 68 \\
\hline БІ-2СД18 & 6 & 250 & 370 & 1,37 & 1,2 & 65 \\
\hline БІІ-3СД12 & 8 & 530 & 530 & 1,37 & - & 66 \\
\hline БІІ-4УД12 & 14 & 445 & 445 & 1,69 & 0,7 & 61 \\
\hline \multicolumn{7}{|c|}{$\begin{array}{l}\text { Notes: } \\
l_{0}-\text { distance from support to critical diagonal crack. For beam series I - distance from support A, } \\
\text { series II - from support B. } \\
l_{\mathrm{sp}}-\text { length of the critical crack along beam axis; } \\
\frac{M}{V \cdot d} \text { - ration in point of critical crack; } \\
\mathrm{W}_{\mathrm{k}}-\text { max. critical crack width. }\end{array}$} \\
\hline
\end{tabular}

Table 5. Parameters of $\mathrm{V}_{\text {theo }} / \mathrm{V}_{\exp }$ for the different design equations

\begin{tabular}{|c|c|c|c|c|c|c|c|}
\hline Until code & $\begin{array}{l}\mathrm{V}_{\text {exp }} \\
\mathrm{kN}\end{array}$ & $\begin{array}{c}\mathrm{V}_{\text {theo, }} \\
\text { (EN 2), } \\
\mathrm{kN}\end{array}$ & $\begin{array}{l}\mathrm{V}_{\text {theo }} / \\
\mathrm{V}_{\exp }\end{array}$ & $\begin{array}{c}\mathrm{V}_{\text {theo, }} \\
\text { (MC 2010), } \\
\mathrm{kN}\end{array}$ & $\begin{array}{l}V_{\text {theo }} / \\
V_{\text {exp }}\end{array}$ & $\begin{array}{c}\mathrm{V}_{\text {theo, }}, \\
\text { (prEN 2), } \\
\mathrm{kN}\end{array}$ & $\begin{array}{l}V_{\text {theo }} / \\
V_{\text {exp }}\end{array}$ \\
\hline $\begin{array}{c}\text { БІ-1СД18 } \\
\text { (without } \\
\text { loaded } \\
\text { cantilever) }\end{array}$ & $\frac{50,2}{62,8}$ & 31,1 & 0.49 & 16,4 & 0,64 & 34,6 & 0,69 \\
\hline БІ-2СД18 & $\frac{34,6}{46,2}$ & 33,1 & 0,71 & 17,6 & 0,48 & 34,8 & 1,01 \\
\hline БІІ-3СД12 & $\frac{25,2}{25,2}$ & 35,7 & 1,42 & 17,7 & 0,71 & 33,3 & 1,32 \\
\hline БІІ-4УД12 & $\frac{25,2}{25,2}$ & 27,9 & 1,11 & 22,9 & 0,91 & 25,7 & 1,02 \\
\hline
\end{tabular}

\section{Conclusion}

The following conclusions can be drawn from the results of the present study:

- the mechanical model of shear resistance based on MCFT (fib MC 2010) cannot be applied to elements reinforced with fiberglass bars (GFRP), since this model has limitations on the strain of concrete in the middle of the element section $\left(\varepsilon_{x} \leq 0.003\right)$. With such a reinforcement, the strain at the level of the middle of the section of the element will be greater due to the low modulus of elasticity of the fiberglass reinforcement;

- the empirical model of shear resistance presented in EN 1992-1-1 also has a limitation that does not allow its use in the design of beam elements loaded with a uniformly distributed load. With this type of loading, where the transverse force varies along the span, a critical inclined crack forms at a distance approximately equal to $\approx d$ from the support, the design section in this model is taken at a distance of $0.5 d$ from the support, which in turn will underestimate the shear resistance of the element; 
- mechanical model CSCT (prEN 1992-1-1) has a fairly high level of accuracy. However, it should be noted that this model is not without its drawbacks.

- on the basis of studies [14-17], in rigid beams (at $L / d<10$ ), failure occurs when fracture of concrete above the tip of a critical crack, which was not observed when testing beams reinforced with polymer composites (see Figure 4). A detailed theoretical analysis of the results obtained is required.

\section{References}

1. ACI Committee 440 Guide for the design and construction of structural concrete reinforced with FRP bars. (2006)

2. ACI Committee 445, ACI J. Pr., 70 (1973)

3. R. Machial, M. S. Alam, A. Rteil, M. and Str., 45 (2001)

4. A. Ghowdhury, I. Mashfiqul, J. of C. and Env. Eng., doi: 10.4172/2165-784x.1000186. (2015)

5. T. Zhang, J. Oehlers, P. Visintin, J. of Comp. C., 18 (2014)

6. S. Lee, C. Lee, Eng. Str., 61, 99 (2014)

7. L. C. Hoang, U. G. Jensen, M. of Concr. Res., 62, 625 (2010)

8. L. C. Hoang, M. P. Nielsen, Cem. and Concr. Comp., 20, 437 (1998)

9. U. G. Jensen, L. C. Hoang, M. of Concr. Res., 61, 691 (2009)

10. V. Semianiuk, V. Tur, S. St. Phen., 292, 230, doi:10.4028/ www.scientific.net/ ssp.292.230. (2018)

11. European Committee for Standardization. Eurocode 2: Design of Concrete Structures, Part 1-1: General rules and rules for buildings, 293 (2018)

12. fib Model Code for Concrete Structures 2010. - Ernst and Sohn, 389 (2013)

13. European Committee for Standardization. Eurocode 2: Design of Concrete Structures, Part 1: General rules, rules for buildings, bridges and civil engineering structures. Draft for committee works, 293 (2018)

14. N. A. Dassow, Msc thesis. Austin (USA): The University of Texas. 117 (2014)

15. A. Caldentey Perez, ACI Str. J., 109, 595 (2012)

16. F. Cavagnis, PhD thesis, Structural concrete laboratory (IBETON), École polytechnique fédérale de Lausanne (EPFL), Lausanne, Switzerland. 201 (2017)

17. B. A. Podgorniak-Stanik, Msc. Thesis. Toronto (Canada): The University of Toronto. $711(1998)$ 